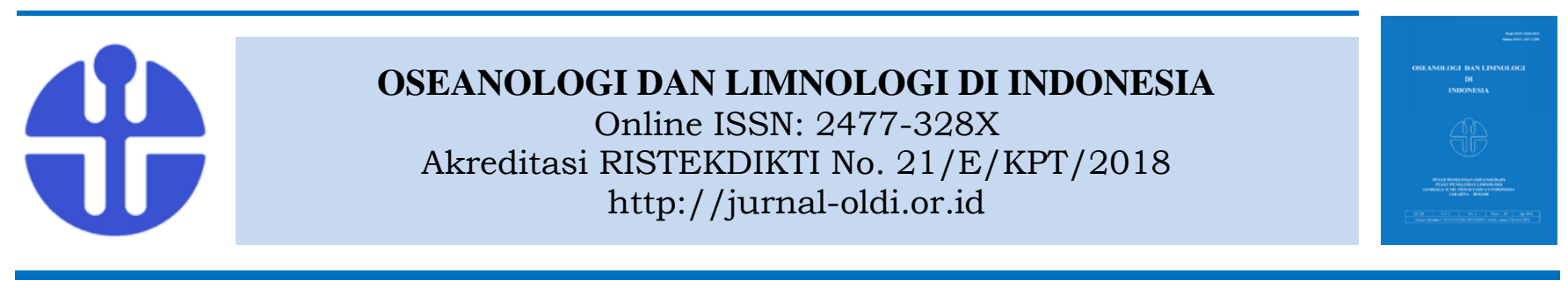

\title{
Dinamika Massa Air di Sekitar Pulau-Pulau Kecil Terluar (PPKT) Perairan Utara Papua
}

\author{
Dewi Surinati ${ }^{1}$ dan Corry Corvianawatie ${ }^{1,2,3}$ \\ ${ }^{1}$ Pusat Penelitian Oseanografi, Lembaga Ilmu Pengetahuan Indonesia, Jakarta, Indonesia \\ ${ }^{2}$ Institute of Oceanology Chinese Academy of Sciences (IOCAS), QingDao, China \\ ${ }^{3}$ University of Chinese Academy of Sciences (UCAS), Beijing, China \\ E-mail: dewi012@lipi.go.id dan dewi.surinati@gmail.com
}

Submitted 29 Maret 2019. Reviewed 19 August 2019. Accepted 10 November 2019.

DOI: 10.14203/oldi.2019.v4i3.251

\begin{abstract}
Abstrak
Perairan sekitar Pulau-Pulau Kecil Terluar (PPKT) di Utara Papua memiliki potensi sumber daya laut yang tinggi dan perlu dikelola secara berkelanjutan. Agar proses konservasi, rehabilitasi, pemanfaatan, dan pengayaannya berjalan dengan baik maka perlu suatu kajian daya dukung lingkungan yang melibatkan analisis dinamika oseanografi di perairan sekitar PPKT. Area penelitian ini mencakup perairan pesisir dan lepas pantai Pulau Jiew, Budd, Fani, Bras dan Fanildo. Pengukuran karakteristik massa air dan arus laut dilakukan untuk mengetahui pengaruh dinamika oseanografi regional terhadap kondisi oseanografi di pesisir PPKT. Hasil penelitian menunjukkan adanya dominasi oleh New Guinea Coastal Current (NGCC) di lapisan permukaan, pengaruh arus lintas Indonesia (Arlindo) di kedalaman $100-150 \mathrm{~m}$, dan arus balik ke arah timur laut yang diduga merupakan perpanjangan New Guinea Costal Under Current (NGUGC) dan Equatorial Under Current (EUC). Sistem arus ini membawa massa air South Pacific Subtropical Water (SPSW) yang ditandai dengan salinitas maksimum sebesar 35,4 PSU pada kedalaman $150 \mathrm{~m}$. Variabilitas spasial ketebalan mixed layer dan kemiringan pada kurva T-S teridentifikasi di sisi barat dan timur area penelitian yang diduga disebabkan oleh percampuran isopiknal. Namun, suhu permukaan laut (SPL) di area ini relatif hangat sepanjang tahun karena adanya Western Pacific Warm Water Pool. Dengan adanya variasi SPL tahunan yang kecil, arus laut, dan percampuran massa air yang cukup kuat di beberapa lokasi, area ini memiliki potensi untuk pengembangan ekosistem kelautan.
\end{abstract}

Kata Kunci: dinamika, massa air, pulau kecil, pulau terluar, utara Papua

\begin{abstract}
Water Mass Dynamics Around the Indonesia's Outer Small Islands at North Papua Waters. Coastal area of Indonesia's Outer Islands (PPKT) at North Papua Waters have a huge potential of marine resources which needs to be managed in sustainable ways. In order to make the processes of protection, conservation, rehabilitation, utilization, and enrichment of coastal resources work well, the study about environmental carrying capacity which includes ocean dynamics analysis around PPKT area is needed. Hereby, the study area were including coastal and off shore area of Jiew, Budd, Fani, Bras and Fanildo Island. The measurement of water mass and ocean current was conducted to analyze the impact of regional ocean dynamics to coastal waters of PPKT. This study found the domination of New Guinea Coastal Current (NGCC) at surface layer, the effect of Indonesian throughflow at subsurface layer $(100-150 \mathrm{~m}$ depth), and counter
\end{abstract}




\section{Surinati \& Corvianawatie}

current towards northeast which is believed as a part of New Guinea Coastal Under Current (NGCUC) and Equatorial Under Current (EUC). This ocean current system carried South Pacific Subtropical Water (SPSW) noticed by maximum salinity of $35.4 \mathrm{PSU}$ at $150 \mathrm{~m}$ depth. There are spatial variability of mixed layer depth and slope of T-S curve at the western and eastern part of study area which might be caused by isopycnal mixing. However, the spatial and temporal variability of Sea Surface Temperature at this area is relatively small due to the presence of Western Paicific Warm Water Pool. With the small annual SST variability, strong ocean current and water mass mixing, this area has a potential for the development of marine ecosystem.

Keyword: dynamics, water mass, small islands, outer islands, north Papua

\section{Pendahuluan}

Indonesia merupakan salah satu negara kepulauan terbesar di dunia dengan total 16.056 pulau (BPS, 2018). Berdasarkan Keputusan Presiden Nomor 6 Tahun 2017, sebanyak 111 pulau-pulau kecil terluar (PPKT) menjadi titik pangkal perbatasan wilayah Indonesia dengan negara lain. Beberapa pulau di perairan Utara Papua dan Laut Halmahera yang ditetapkan sebagai PPKT yaitu Pulau Liki, Bepondi, Brass, Fanildo, Miossu, Fani, Budd, dan Jiew. Meskipun lokasinya relatif jauh dari daratan utama Pulau Papua, keanekaragaman sumber daya hayati laut yang tinggi di perairan sekitar PPKT menjadikan area tersebut sebagai lokasi nelayan untuk mencari ikan, serta memiliki potensi yang tinggi untuk pengembangan wisata bahari. Namun begitu, adanya variabilitas parameter fisis oseanografi seperti suhu, salinitas, oksigen terlarut, dan arus laut dapat memengaruhi produktivitas primer (Gordon, 2005) dan ekosistem pesisir di area ini. Sebagaimana diketahui, wilayah perairan sekitar PPKT berbatasan langsung dengan Samudera Pasifik, sehingga kombinasi antara pola monsunal dan sistem arus regional di Samudera Pasifik bagian barat diduga memengaruhi dinamika oseanografi di perairan sekitar PPKT.

Pengaruh sistem angin monsun terhadap dinamika oseanografi perairan Utara Papua dan Laut Halmahera (Wyrtki, 1961) terlihat pada adanya variabilitas arus laut di lapisan permukaan. Arus permukaan laut di pesisir Pulau Papua dominan bergerak ke arah timur pada monsun Barat Laut, sebaliknya dominan bergerak ke arah barat pada monsun Tenggara (Wyrtki, 1961). Selain sistem angin monsun, area ini dipengaruhi oleh angin pasat yang dominan berhembus ke arah barat sepanjang tahun. Pada kondisi normal, sistem angin pasat mendorong massa air dari Samudera Pasifik bagian tengah menuju Samudera Pasifik bagian barat dan mengakumulasikan massa air hangat di area ini. Oleh karena itu wilayah Perairan Samudera Pasifik bagian barat yang mencakup
Perairan Utara Papua dikenal juga sebagai kolam air hangat Samudera Pasifik barat. Area ini memiliki rata-rata suhu permukaan laut paling tinggi di dunia yaitu mencapai $>28{ }^{\circ} \mathrm{C}$ (Potemra \& Qu, 2010; Supangat et al., 2015; De Deckker, 2016). Pergeseran spasial dan temporal dari kolam hangat ini sangat terkait dengan pergerakan meridional matahari yang memengaruhi besarnya intensitas penyinaran matahari di belahan bumi bagian utara dan selatan (Supangat et al., 2015).

Selain berperan dalam pembentukan kolam air hangat, angin pasat juga diketahui memiliki peran penting dalam pembentukan fenomena $\mathrm{El}$ Niño Southern Oscillation (ENSO) (Philander, 1983), yang selanjutnya memengaruhi kondisi oseanografi di Perairan Utara Papua. Area ini akan diisi oleh massa air yang lebih dingin dari lapisan bawah karena proses upwelling pada kondisi El Niño, sebaliknya suhu permukaan laut akan lebih hangat pada kondisi La Niña. Variasi suhu air laut di Perairan Utara Papua dan Halmahera yang dipengaruhi oleh ENSO berkaitan dengan terbentuknya cyclonic dan anticyclonic eddies yang menyebabkan proses upwelling dan downwelling (Simanungkalit et al., 2018). Tingginya suhu air laut pada kondisi La Niña disebabkan oleh terbentuknya anticyclonic eddies yang membuat adanya konvergensi massa air hangat di pusat $e d d y$. Demikian juga halnya di perairan timur Australia yang berada di belahan bumi selatan, siklon Eddy mendorong upwelling dengan terekspornya massa air yang lebih dingin dan lebih tinggi klorofilnya (Ismail \& Ribbe, 2019).

Perairan Utara Papua juga dikenal sebagai jalur sekunder pada sistem arus lintas Indonesia (Arlindo). Arlindo atau yang lebih dikenal sebagai Indonesian throughflow (ITF) merupakan bagian dari siklus termohalin, yang berperan dalam mentransfer massa air dan kalor dari Samudera Pasifik menuju Samudera Hindia melewati perairan Indonesia (Fine et al., 1994; Gordon \& Fine, 1996; Gordon et al., 2010). Sumber utama ITF adalah massa air subtropis Pasifik Utara (North 
Pacific Subtropical Water - NPSW) yang dibawa oleh arus ekuatorial utara (North Equatorial Current - NEC) bergabung dengan arus Mindanao dan berbelok menuju Laut Sulawesi dan Selat Makassar (Fine et al., 1994). Sedangkan jalur kedua ITF berasal dari arus ekuatorial selatan (South Equatorial Current-SEC) dan arus pesisir Papua Nugini (New Guinea Coastal Current $N G C C$ ) menuju perairan Indonesia. Jalur sekunder ini diketahui membawa massa air subtropis Pasifik Selatan (South Pacific Subtropical Water - SPSW) melalui Laut Halmahera (Li et al., 2018), Laut Seram, Laut Banda, hingga Samudera Hindia. Namun begitu, massa air SPSW yang masuk menuju perairan Indonesia mengalami transformasi oleh proses percampuran isopiknal ataupun diapiknal karena adanya pertemuan dengan massa air NPSW di beberapa area, khususnya di bagian utara Laut Halmahera (Li et al., 2018). Proses lainnya seperti percampuran oleh pasang surut baroklinik diduga memegang peranan penting dalam proses transformasi massa air di perairan Indonesia (Koch-Larrouy et al., 2008)

Kombinasi antara kompleksnya sistem arus dan batimetri di Perairan Utara Papua menyebabkan adanya variabilitas spasial massa air baik dalam arah horizontal maupun vertikal. Beberapa studi terkait kondisi oseanografi di perairan Utara Papua sudah dilakukan (Li et al., 2018; Wattimena et al., 2018), namun belum spesifik melihat pengaruhnya terhadap kondisi oseanografi di sekitar PPKT. Oleh karena itu, untuk menganalisis profil massa air dan arus laut di perairan sekitar PPKT wilayah Utara Papua, observasi kondisi oseanografi terkini di area tersebut telah dilakukan dalam Ekspedisi Nusa Manggala tahun 2018. Penelitian ini bertujuan untuk menganalisis variabilitas spasial massa air dan arus laut di area lepas pantai dan pengaruhnya terhadap kondisi oseanografi di pesisir PPKT. Hasil penelitian ini diharapkan dapat bermanfaat untuk pengembangan wilayah pesisir khususnya berkaitan dengan produktivitas primer dan ekosistem pesisir.

\section{Metodologi}

Observasi kondisi oseanografi merupakan salah satu bagian dalam Ekspedisi Nusa Manggala tahun 2018 (ENM 2018). Penelitian pada bagian pertama ENM yang dilaksanakan pada tanggal 27 Oktober - 13 November 2018 mencakup wilayah perairan di sekitar Pulau Jiew, Fani, Budd, Brass, dan Fanildo (Gambar 1). PPKT ini terletak di sebelah utara Pulau Papua dan Laut Halmahera, yang merupakan bagian dari Samudera Pasifik bagian barat. Penelitian dilakukan dengan melakukan pengukuran in situ parameter oseanografi di tujuh stasiun penelitian yang berlokasi di pesisir PPKT dan delapan stasiun penelitian yang berlokasi di lepas pantai (Tabel 1). Profil massa air meliputi suhu, salinitas, dan oksigen terlarut (Dissolved Oxygen - DO) diukur menggunakan Conductivity Temperature Depth (CTD) SBE 911 Plus yang terpasang di Kapal Riset Baruna Jaya VIII. Profil massa air diukur dari lapisan permukaan hingga mendekati dasar perairan. Untuk meminimalisasi adanya gangguan (noise) pada hasil pengukuran massa air, maka dilakukan perata-rataan data parameter oseanografi setiap interval kedalaman 1 meter.

Selain itu dilakukan pula pengukuran profil arus laut di sepanjang lintasan perjalanan kapal (cruise track) dari lapisan permukaan hingga kedalaman maksimum $\sim 600 \mathrm{~m}$ menggunakan Vessel Mounted ADCP (VM-ADCP) Teledyne. Pengukuran secara time series dalam periode $\sim 24$ jam juga dilakukan di sekitar PPKT untuk mengetahui pola harian arus laut di wilayah tersebut. Hasil pengukuran arus laut menggunakan VM-ADCP selanjutnya difilter menggunakan metode median filter untuk menghilangkan gangguan (noise) pada data hasil pengukuran. Gangguan (noise) pada data arus laut secara dominan terlihat pada kedalaman $>250 \mathrm{~m}$. Oleh karena itu, untuk menghindari bias dalam analisis data, pembahasan profil vertikal arus laut dibatasi hingga kedalaman $250 \mathrm{~m}$. Hasil pengukuran arus laut yang sudah difilter tersebut selanjutnya digambarkan sebagai penampang vertikal dan diagram skema arus laut pada beberapa lapisan kedalaman untuk memudahkan proses analisis.

Selain data hasil pengukuran parameter oseanografi secara in situ, data sekunder suhu permukaan laut (SPL) di wilayah Samudera Pasifik Barat dianalisis pula dalam penelitian ini. Data SPL tersebut diperoleh dari hasil citra MODIS Aqua dengan resolusi spasial $4 \quad \mathrm{x} \quad 4 \quad \mathrm{~km}$ (https://giovanni.gsfc.nasa.gov/giovanni/). Data ini dipilih karena resolusi spasialnya yang cukup tinggi dan mewakili kondisi oseanografi di sekitar PPKT. Untuk mengetahui kondisi umum dinamika SPL di area ini, dilakukan perata-rataan bulanan dalam periode tahun 2002-2017. 


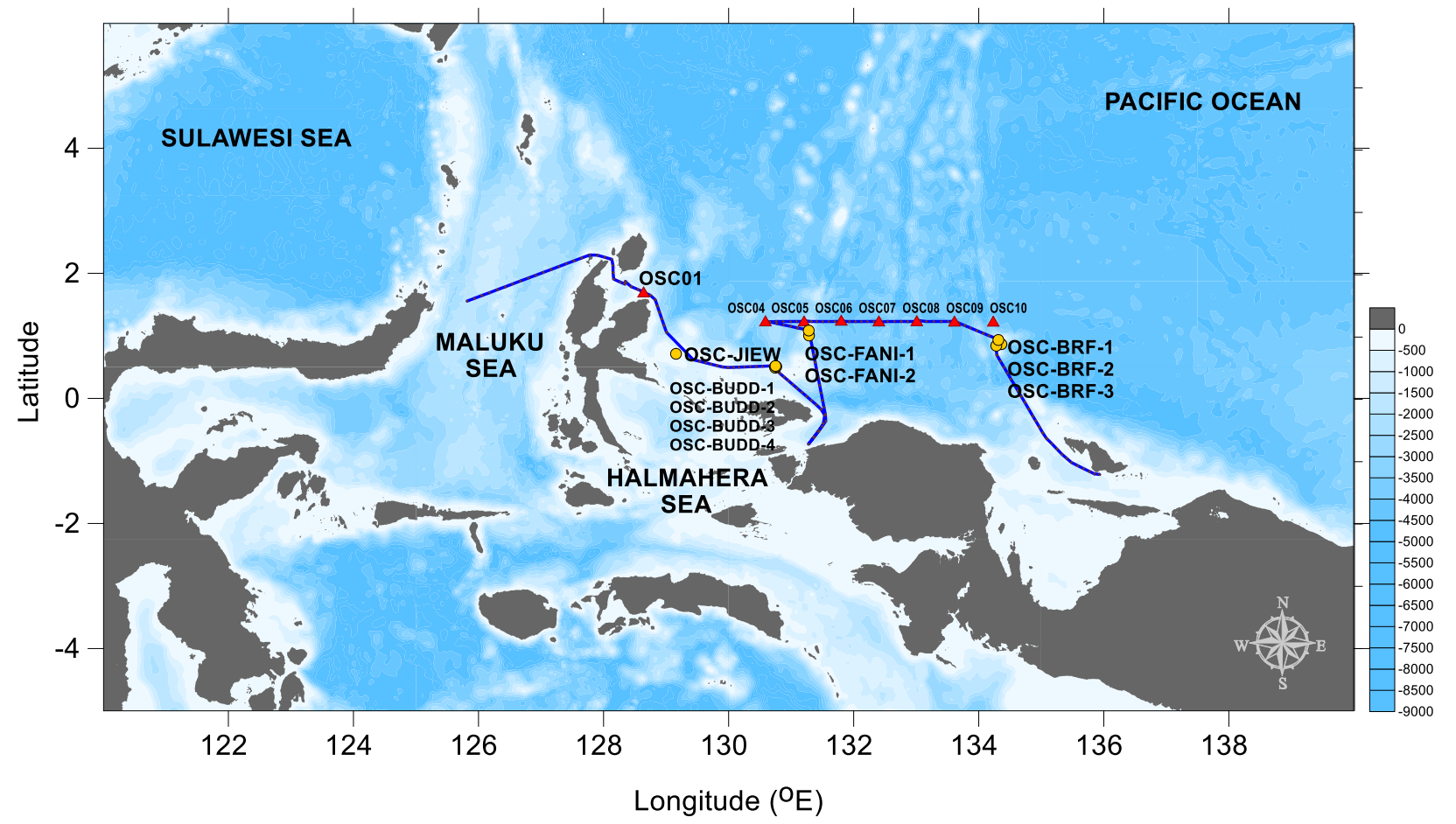

Gambar 1. Lokasi stasiun penelitian oseanografi fisika pada Ekspedisi Nusa Manggala 2018 bagian pertama (leg pertama). Simbol segitiga merah merepresentasikan stasiun penelitian yang berada di lepas pantai (OSC01, OSC04 s.d. OSC10) dan simbol lingkaran kuning merepresentasikan stasiun penelitian di pesisir pantai PPKT. Garis biru merepresentasikan jalur pengukuran arus laut menggunakan VM-ADCP.

Figure 1. Location of physical oceanography research station during the first part of Nusa Manggala Expedition (first leg). Red triangle symbols represent the research stations at off-shore area (OSC01, OSC04.d. OSC10) and yellow circle symbols represent the research stations at coastal area of PPKT. The blue line represents the cruise track of ocean current measurement using VM-ADCP.

\section{Hasil}

\section{Variabilitas Suhu dan Salinitas Permukaan Laut}

Suhu dan salinitas permukaan laut merupakan parameter fisis oseanografi yang memiliki peran penting terhadap ekosistem pesisir. Pengukuran suhu permukaan laut menggunakan CTD di perairan sekitar PPKT Papua Utara menunjukkan bahwa SPL di area ini cenderung homogen. Pengukuran in situ SPL yang dilakukan pada monsun peralihan antara monsun tenggara menuju monsun barat laut menunjukkan adanya variasi SPL secara spasial pada rentang 29,42 $30,23{ }^{\circ} \mathrm{C}$. Tidak terdapat perbedaan yang signifikan antara suhu permukaan laut di wilayah pesisir dan lepas pantai area PPKT. Demikian halnya dengan hasil pengukuran salinitas permukaan laut yang relatif homogen dengan rentang 34,0 hingga 34,28 PSU, kecuali pada stasiun OSC10. Area ini memiliki salinitas yang lebih rendah yaitu sebesar
33,85 PSU yang diduga disebabkan oleh adanya presipitasi pada saat pengukuran.

Untuk memahami lebih baik variabilitas SPL di sekitar PPKT, dilakukan analisis variasi SPL tahunan menggunakan data citra MODIS Aqua yang tersedia selama periode tahun $2002-2017$ (Gambar 2). Massa air dari Samudera Pasifik terlihat jelas dari Gambar 2 memasuki kawasan Indonesia melalui Laut Maluku dan Halmahera pada bulan Juni hingga September, dengan puncaknya adalah sekitar Juli dan Agustus. Berdasarkan data rata-rata bulanan SPL tersebut dapat diketahui bahwa Perairan Utara Papua cenderung memiliki SPL yang relatif hangat sepanjang tahun yaitu $>29^{\circ} \mathrm{C}$. Rata-rata SPL paling tinggi dapat diidentifikasi pada kondisi monsun peralihan I dan II yang terjadi pada bulan Maret Mei (MAM) dan September - November (SON). Pada monsun peralihan SPL di Perairan Utara Papua bervariasi pada rentang 29,5 hingga $31,5{ }^{\circ} \mathrm{C}$ dengan suhu tertinggi berada di pesisir Pulau Papua. Selanjutnya SPL relatif lebih rendah 
teridentifikasi pada monsun Barat Laut dan Tenggara yang terjadi pada bulan Desember Februari (DJF) dan Juni - Agustus (JJA) dengan rentang 29,0 hingga $30,5^{\circ} \mathrm{C}$. Hal ini membuktikan bahwa SPL di Perairan Utara Papua didominasi oleh variabilitas regional Samudera Pasifik bagian barat. Oleh karena itu area ini dikenal juga dengan sebutan kolam air hangat Samudera Pasifik bagian barat karena nilai SPL yang relatif hangat sepanjang tahun (Wyrtki, 1961; Fine et al., 1994; Qu et al., 2005; Supangat, 2015). Kondisi ini sesuai dengan hasil penelitian sebelumnya yang menemukan bahwa perairan di Samudera Pasifik bagian barat didominasi oleh suhu permukaan laut yang relatif hangat $\left(28-29^{\circ} \mathrm{C}\right)$ dan salinitas permukaan yang relatif rendah (33,8 - 34,0 PSU). Massa air ini diketahui membentuk front dengan massa air permukaan dari Samudera Pasifik bagian tengah yang memiliki salinitas lebih tinggi yaitu 34,0 - 34,6 PSU (Supangat et al., 2015).
Berbeda halnya dengan perairan di sekitarnya seperti Laut Halmahera, Laut Maluku, Laut Seram, dan Laut Banda yang memiliki variabilitas SPL tahunan lebih tinggi. Perbedaan SPL secara signifikan terlihat pada kondisi monsun tenggara (JJA), yaitu Perairan Utara Papua memiliki suhu yang jauh lebih hangat dibandingkan perairan di sekitarnya. SPL di Perairan Utara Papua berada pada rentang 29,0 hingga $30,5^{\circ} \mathrm{C}$, sedangkan SPL di Laut Halmahera, Laut Maluku, Laut Seram, dan Laut Banda berada pada rentang $27-29^{\circ} \mathrm{C}$. SPL yang relatif rendah ini juga ditemui hingga memasuki monsun peralihan yaitu pada bulan September - Oktober. Namun memasuki monsun barat (DJF) dan monsun peralihan I (MAM) perbedaan suhu antara Perairan Utara Papua dan laut-laut di sekitarnya tidak berbeda secara signifikan.
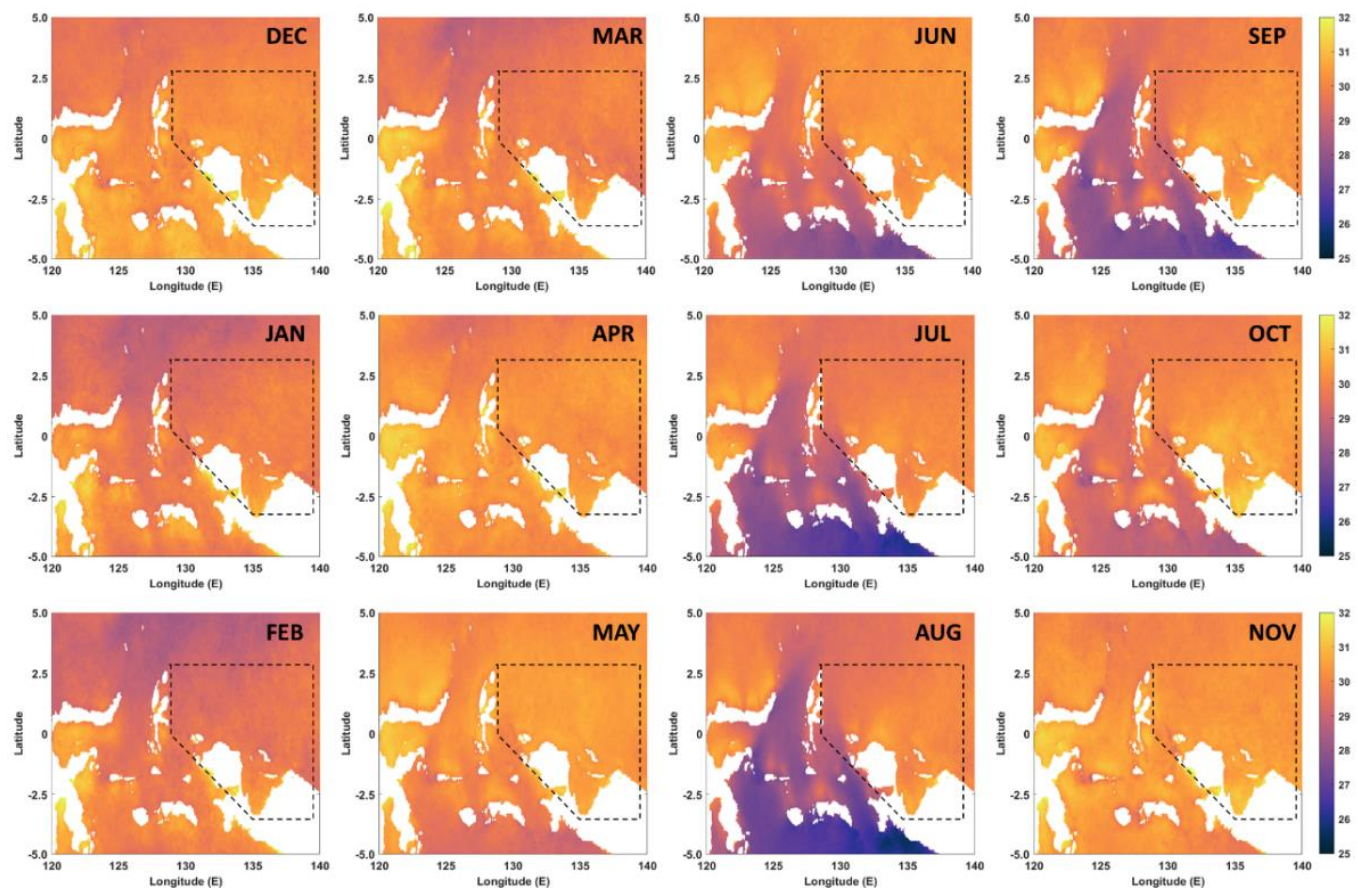

Gambar 2. Rata-rata bulanan SPL di perairan Indonesia bagian timur berdasarkan data MODIS Aqua dengan resolusi spasial 4 x $4 \mathrm{~km}$ selama tahun 2002 - 2017. Area dalam garis putus-putus menggambarkan daerah kajian yaitu perairan sekitar PPKT.

Figure 2. Monthly average sea surface temperature (SST) at the Eastern Indonesian Seas based on MODIS Aqua data with 4 x $4 \mathrm{~km}$ spatial resolutions during $2002-2017$ periods. Northern Papua Water were represented insides the dashed line polygon. 

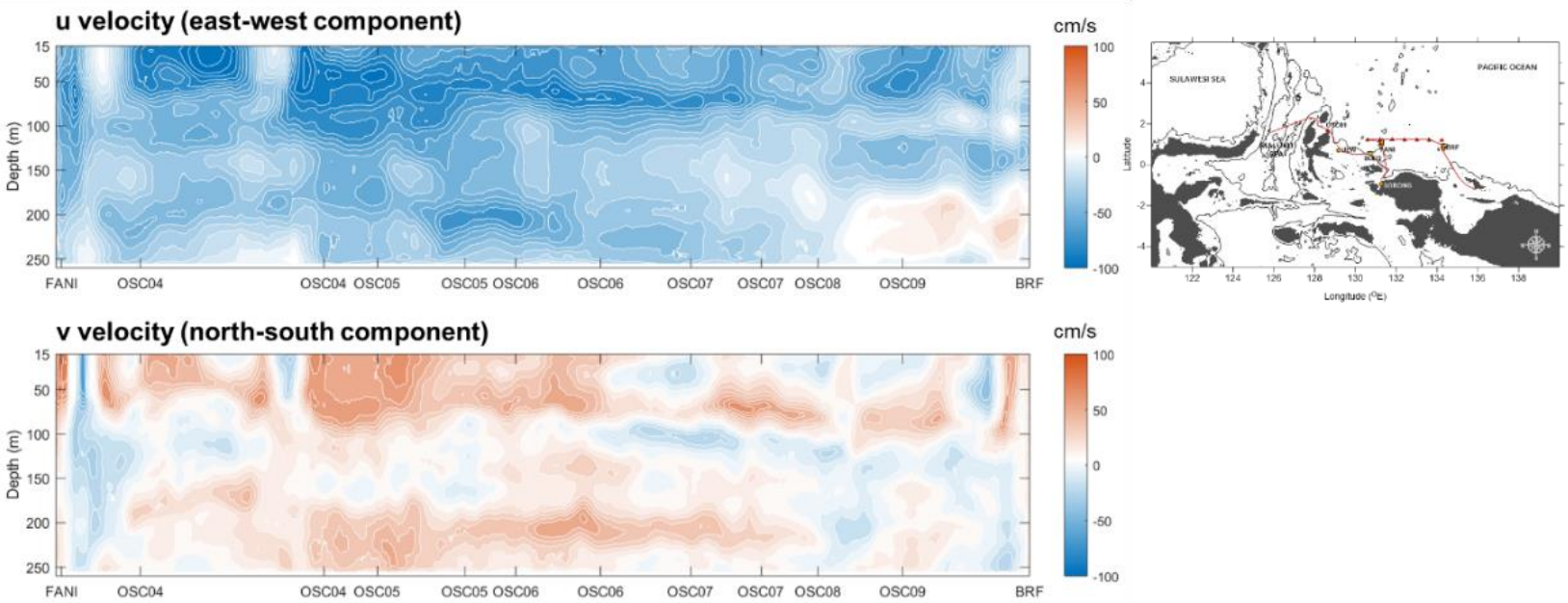

Gambar 3. Profil vertikal arus laut komponen timur-barat (u-velocity) dan utara-selatan (v-velocity) di Perairan Utara Papua (penampang Pulau Fani - OSC01 - OSC04 - OSC10 - Pulau Brass dan Fanildo) dalam $\mathrm{cm} / \mathrm{s}$.

Figure 3. Ocean current profile of east-west component (u-velocity) and north-west component (v-velocity) at Maluku and Halmahera Sea (sections of Fani Island - OSC01 - OSC04 - OSC10 - Brass and Fanildo Island) in $\mathrm{cm} / \mathrm{s}$.
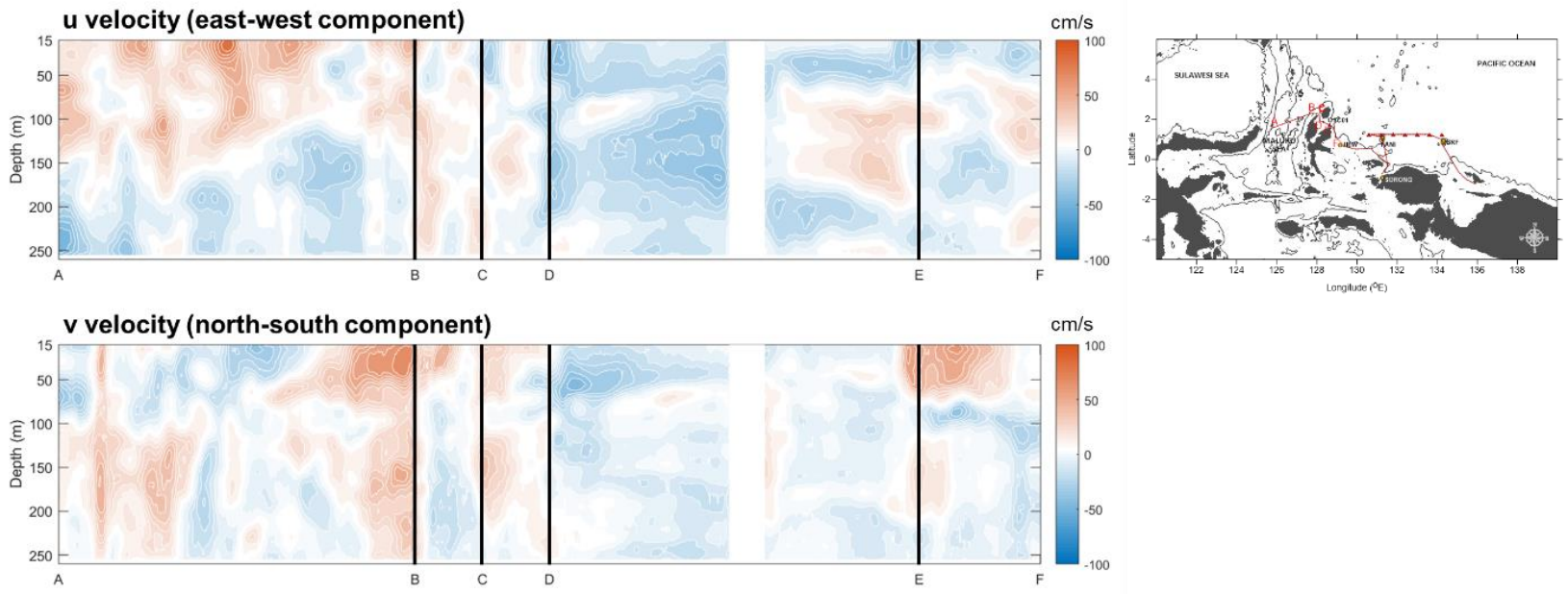

Gambar 4. Profil vertikal arus laut komponen timur-barat (u-velocity) dan utara-selatan (v-velocity) di Laut Maluku dan Halmahera (penampang A-F) dalam $\mathrm{cm} / \mathrm{s}$.

Figure 4. Ocean current profile of east-west component (u-velocity) and north-west component (v-velocity) at Maluku and Halmahera Sea (A-F sections) in cm/s.

\section{Profil Arus Laut di Perairan Utara Papua, Laut Halmahera, dan Laut Maluku}

Variabilitas suhu dan salinitas permukaan laut erat kaitannya dengan fluks panas dan fluks air tawar antara laut dan atmosfer (Halkides et al., 2011), serta sirkulasi arus laut di suatu wilayah perairan. Untuk memahami pola arus laut di sekitar PPKT, pengukuran profil arus laut dilakukan di sepanjang jalur lintasan ENM 2018 yang meliputi 192 bagian utara Laut Maluku, Laut Halmahera, dan Perairan Utara Papua. Pada lapisan permukaan yaitu pada kedalaman $\sim 13$ hingga $100 \mathrm{~m}$, arus laut di Perairan Utara Papua dominan bergerak ke arah barat hingga barat laut. Adapun kecepatan arus laut berkisar antara 80 hingga $110 \mathrm{~cm} / \mathrm{s}$ (Gambar 3). Hasil ini sesuai dengan beberapa penelitian sebelumnya yang menyatakan bahwa arus permukaan laut di area ini didominasi oleh arus 
pesisir Papua Nugini (New Guinea Coastal Current - NGCC) dan arus ekuatorial selatan (South Equatorial Current - SEC) (Fine et al., 1994). Kondisi yang hampir sama teridentifikasi di sebelah utara Laut Halmahera (di sekitar Pulau Jiew, Budd, dan Fani) yang didominasi oleh arus laut yang bergerak ke arah barat laut dengan kecepatan arus 10 hingga $60 \mathrm{~cm} / \mathrm{s}$ (Gambar 4). Kondisi ini diduga disebabkan oleh adanya angin pasat tenggara yang mendominasi pada monsun peralihan tersebut. Berbeda halnya dengan pola arus laut permukaan di Laut Maluku, terlihat adanya perbedaan arah arus antara sisi barat dan sisi timur (Gambar 4, penampang A-B). Di sisi barat Laut Maluku, arus permukaan laut bergerak ke tenggara atau masuk ke perairan Indonesia dengan kecepatan 30 hingga $60 \mathrm{~cm} / \mathrm{s}$. Sebaliknya arus permukaan laut di sisi timur Laut Maluku bergerak ke arah barat laut hingga utara dengan kecepatan 50 hingga $90 \mathrm{~cm} / \mathrm{s}$.

Pola arus yang sedikit berbeda terlihat pada kedalaman $100-150 \mathrm{~m}$. Di perairan utara Papua, arus laut dominan bergerak ke arah barat laut hingga barat daya memasuki perairan Indonesia dengan kecepatan 40 hingga $80 \mathrm{~m} / \mathrm{s}$. Arus ini diduga merupakan sumber masuknya massa air Samudera Pasifik ke perairan Indonesia melalui sistem ITF (Gordon \& Fine, 1996; Gordon et al., 2010; Sprintall et al., 2014; Yuan et al., 2018). Di Laut Halmahera, arus memasuki perairan Indonesia melalui sisi barat dan keluar melalui sisi timur. Hasil penelitian ini menunjukkan pola yang hampir sama dengan penelitian sebelumnya di area ini yang menujukkan bahwa pada kedalaman $100-$ $150 \mathrm{~m}$, arus dominan bergerak ke arah selatan. Namun di sisi kanan dan kiri dari arus yang kuat ini terdapat arus balik ke arah utara (Wattimena et al., 2018). Kondisi yang berbeda terlihat pula di Laut Maluku yang menunjukkan dominasi arus yang bergerak ke arah utara. Kondisi ini sesuai dengan hasil pengukuran arus laut menggunakan sistem mooring yang menunjukkan bahwa pada bulan Oktober hingga Februari, arus laut di Laut Maluku cenderung bergerak ke utara hingga timur laut (Yuan et al., 2018).

Selanjutnya di kedalaman $200-250 \mathrm{~m}$, arus laut mulai melemah dengan kecepatan 10 $40 \mathrm{~cm} / \mathrm{s}$ (Gambar 3). Di perairan utara Papua arus mengalami pembelokan ke arah timur laut. Arus ini diduga merupakan perpanjangan dari New Guinea Coastal Under Current (NGCUC) dan Equatorial Under Current (EUC) (Fine et al., 1994). Kedua arus ini bergerak ke arah utara dan membelok ke arah timur. Namun begitu, arus laut yang mengarah masuk ke ke wilayah perairan Indonesia masih terlihat di Laut Halmahera bagian barat, sedangkan di bagian timur didominasi oleh arus yang bergerak ke arah timur laut (Gambar 4). Pola arus yang berbeda juga terlihat di Laut Maluku, yaitu di suatu kanal sempit di sisi barat dan timur Laut Maluku yang didominasi oleh arus yang bergerak keluar dari perairan Indonesia (Gambar 4). Sebaliknya di sisi tengah Laut Maluku terlihat adanya arus laut yang bergerak masuk menuju perairan Indonesia.

\section{Profil Arus Laut di Perairan Pesisir PPKT}

Pengukuran arus laut dilakukan pula di sekitar pesisir PPKT untuk mengetahui pola harian arus laut di area tersebut. Pengukuran arus di Pesisir Pulau Jiew dilakukan pada kedalaman 15 $30 \mathrm{~m}$ (Gambar 5a). Hasil pengukuran menunjukkan bahwa area ini didominasi oleh arus pasang surut. Dalam periode pengukuran selama satu hari terlihat adanya pola arus yang mengikuti pola gelombang pasang surut dengan tipe semidiurnal, yaitu dua kali pasang dan dua kali surut dalam satu hari. Pola arus pasang surut ini ditandai dengan adanya arah arus yang berkebalikan antara kondisi pasang dan surut. Adapun kecepatan arus laut di kedalaman $15 \mathrm{~m}$ cukup kuat yaitu berkisar antara 0 hingga $70 \mathrm{~cm} / \mathrm{s}$. Seiring dengan bertambahnya kedalaman, arus mengalami pengurangan kecepatan. Namun begitu, pola arus pasang surut tetap terlihat hingga kedalaman $30 \mathrm{~m}$.

Berbeda halnya dengan Pulau Jiew, arus permukaan laut di Pulau Budd tidak menunjukkan pengaruh pasang surut yang cukup jelas (Gambar 5b). Pada kedalaman 15 dan $50 \mathrm{~m}$ arus laut dominan bergerak ke arah barat laut hingga barat daya. Arus laut pada kedalaman $15 \mathrm{~m}$ cukup kuat yaitu berada pada rentang $0-80 \mathrm{~cm} / \mathrm{s}$, sedangkan di kedalaman $50 \mathrm{~m}$ arus laut melemah yaitu berada pada rentang $0-50 \mathrm{~cm} / \mathrm{s}$. Selanjutnya, pada kedalaman $100 \mathrm{~m}$ arus laut berbalik ke arah tenggara dengan kecepatan $0-30 \mathrm{~cm} / \mathrm{s}$. Di bawah lapisan ini yaitu pada kedalaman $150 \mathrm{~m}$ arus laut semakin melemah dengan kecepatan $0-10 \mathrm{~cm} / \mathrm{s}$. Arus di lapisan ini dominan bergerak ke arah barat laut hingga timur laut. 
Surinati \& Corvianawatie
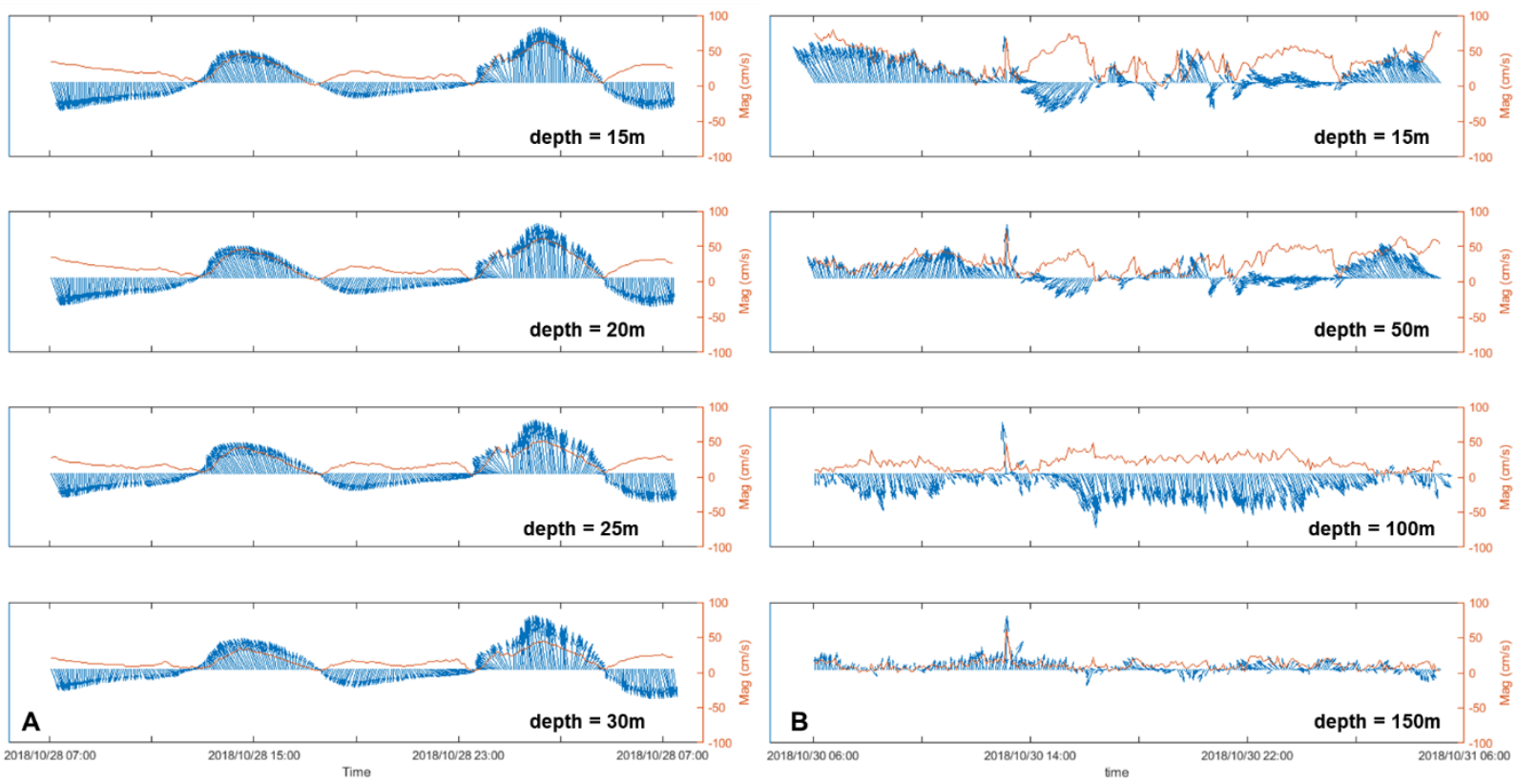

Gambar 5. Hasil pengukuran arus laut di a) Pulau Jiew pada kedalaman 15 - 30 m dan b) Pulau Budd pada kedalaman $15-150 \mathrm{~m}$.

Figure 5. Measured ocean current profile at a) Jiew Island in $15-30 \mathrm{~m}$ depth and b) Budd Island in $15-150$ m depth.
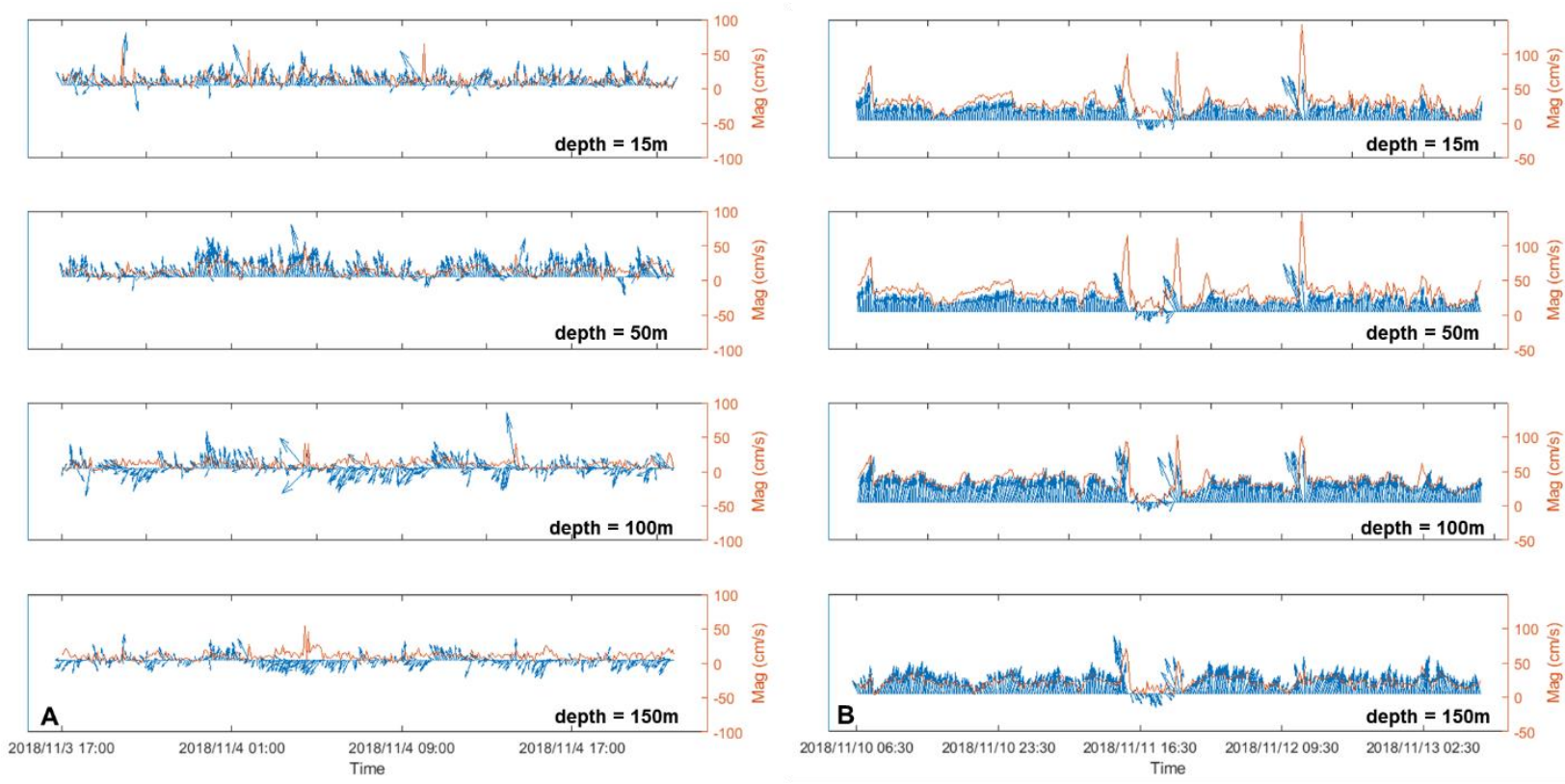

Gambar 6. Hasil pengukuran arus laut di a) Pulau Fani dan b) Pulau Brass dan Fanildo pada kedalaman 15 $150 \mathrm{~m}$.

Figure 6. Measured ocean current profile at a) Fani Island and b) Brass and Fanildo Island in $15-150$ m depth.

Arus permukaan laut di Pulau Jiew dan Pulau Budd tergolong cukup kuat, namun berbeda halnya dengan hasil pengukuran arus laut di Pulau Fani. Arus laut di area ini lebih lemah yaitu berada 194 pada rentang $0-20 \mathrm{~cm} / \mathrm{s}$ pada kedalaman $15-150$ $\mathrm{m}$ (Gambar 6a). Adapun arus laut di kedalaman 15 $\mathrm{m}$ dan $50 \mathrm{~m}$ dominan bergerak ke arah barat laut hingga timur laut. Sedangkan di kedalaman 100 
dan $150 \mathrm{~m}$ arus laut dominan bergerak ke arah barat laut hingga barat daya.

Di antara ketiga pulau lainnya, Pulau Brass dan Fanildo terletak paling timur. Arus laut di area ini cukup kuat dengan rentang $0-100 \mathrm{~cm} / \mathrm{s}$ di kedalaman $15 \mathrm{~m}$ (Gambar 6b). Arus laut dominan bergerak ke arah utara hingga barat laut. Arus laut di area ini merupakan perpanjangan NGCC yang bergerak ke arah barat dan mengalami pembelokan ke arah barat laut oleh angin monsun. Di kedalaman $50 \mathrm{~m}$, arus masih menunjukkan pola dan kekuatan yang hampir sama dengan pola arus di kedalaman $15 \mathrm{~m}$. Selanjutnya di kedalaman 100 $\mathrm{m}$ dan $150 \mathrm{~m}$ arus laut bergerak ke arah utara hingga timur laut. Adanya pembelokan arah arus ini diduga merupakan perpanjangan arus laut dalam arah vertikal untuk bergabung menjadi NGCUC.

\section{Massa Air di Perairan Utara Papua}

PPKT yang berada di Perairan Utara Papua dan Laut Halmahera terbentang pada area 128 $134^{\circ} \mathrm{BT}$ dan $0-2^{\circ} \mathrm{LU}$. Lokasi PPKT relatif jauh dari daratan utama Pulau Papua maupun Kepulauan Halmahera. Hasil pengukuran pada monsun peralihan II menunjukkan bahwa suhu permukaan laut di area ini bervariasi pada rentang $29,42-30,23{ }^{\circ} \mathrm{C}$. Hasil pengukuran profil vertikal massa air di lepas pantai PPKT menunjukkan adanya lapisan tercampur sempurna (mixed layer) yang cukup jelas dari permukaan hingga kedalaman 80 - 100 m (Gambar 7). Di bawah lapisan ini, suhu air laut berkurang secara drastis terhadap bertambahnya kedalaman atau disebut juga sebagai lapisan termoklin. Dengan meninjau batas lapisan termoklin pada suhu $12,0-25,0^{\circ} \mathrm{C}$ (Wyrtki, 1961), massa air di area ini memiliki lapisan termoklin yang cukup tebal yaitu $\sim 200 \mathrm{~m}$. Batas atas dan batas bawah lapisan termoklin ditentukan berdasarkan perubahan gradien pengurangan suhu terhadap bertambahnya kedalaman yaitu $\mathrm{dT} / \mathrm{dz} \leq-0.1^{\circ} \mathrm{C} / \mathrm{m}$ (Aji et al., 2017). Mixed layer di stasiun OSC04 - OSC06 lebih tipis dibandingkan dengan OSC07 - OSC10. Batas atas lapisan termoklin di OSC04 - OSC06 yaitu pada kedalaman $80 \mathrm{~m}$, sedangkan batas atas lapisan termoklin di OSC07 - OSC10 berada pada kedalaman $100 \mathrm{~m}$. Perbedaan kedalaman juga terlihat pada batas bawah lapisan termoklin (suhu $12^{\circ} \mathrm{C}$ ). Massa air di stasiun OSC04 - OSC06 memiliki batas bawah lapisan termoklin pada kedalaman yang lebih dangkal ( 300 m) daripada massa air di stasiun OSC07 - OSC10 ( 320 - 350 $\mathrm{m})$. Di bawah lapisan ini disebut juga sebagai lapisan dalam (deep layer) karena pengurangan suhu air laut secara perlahan seiring dengan bertambahnya kedalaman. Pada kedalaman 3000 $\mathrm{m}$, suhu potensial air laut mencapai $\sim 2{ }^{\circ} \mathrm{C}$.
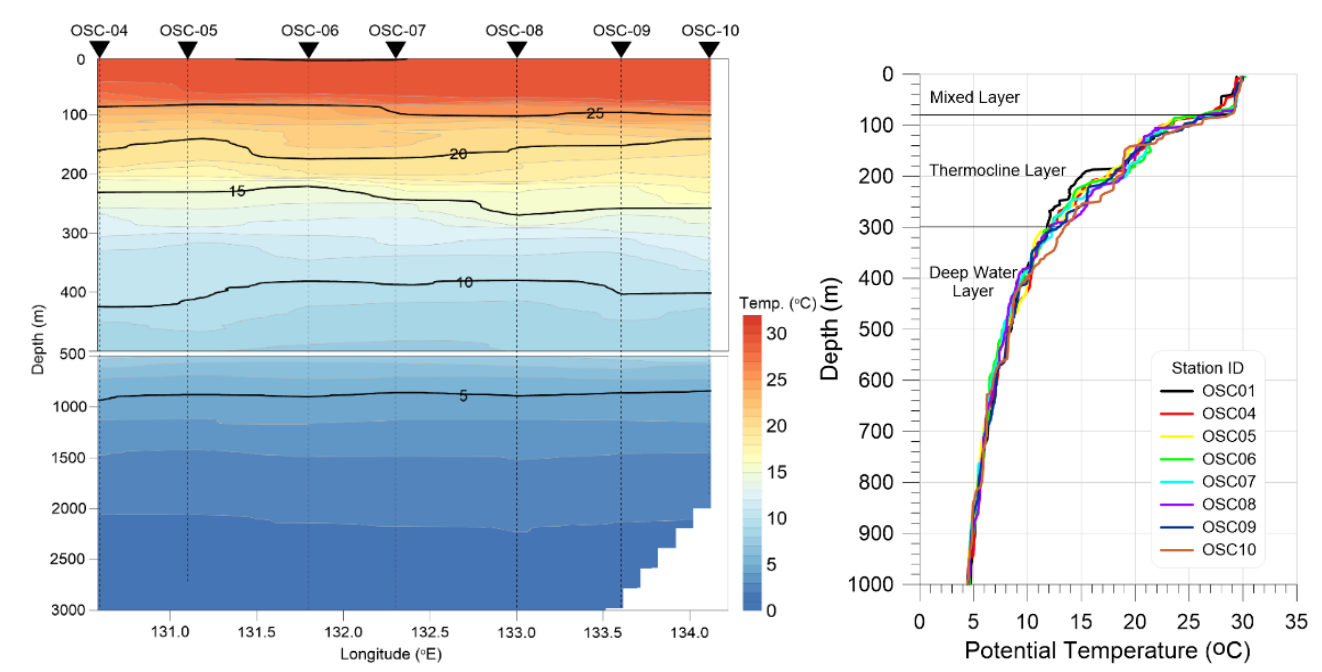

Gambar 7. a) Penampang vertikal suhu potensial air laut dari permukaan hingga kedalaman $3000 \mathrm{~m}$ pada transek OSC04 - OSC10 dan b) profil vertikal suhu potensial air laut di OSC01 dan OSC04 OSC10 dari permukaan hingga kedalaman $1000 \mathrm{~m}$.

Figure 7. a) Vertical section of potential temperature from surface to $3000 \mathrm{~m}$ depth at OSC04-OSC10 transect and b) vertical profile of potential temperature at $\mathrm{OSC} 01$ and $\mathrm{OSC} 04-\mathrm{OSC} 10$ from the surface layer to $1000 \mathrm{~m}$ depth. 


\section{Surinati \& Corvianawatie}

Salinitas permukaan laut bervariasi pada rentang 33,85 - 34,28 PSU. Salinitas air laut membentuk profil yang sedikit berbeda dengan profil suhu. Mixed layer tidak dapat dilihat secara jelas pada profil salinitas. Hal ini dikarenakan kondisi salinitas air laut di lapisan permukaan terus meningkat seiring dengan bertambahnya kedalaman. Pada kedalaman $80 \mathrm{~m}$, salinitas air laut sudah mencapai nilai 35,0 PSU (Gambar 8). Salinitas terus meningkat hingga mencapai nilai $\sim 35,4$ PSU pada kedalaman $\sim 150 \mathrm{~m}$. Posisi salinitas maksimum ini berbeda-beda di setiap stasiun penelitian. Posisi salinitas maksimum di stasiun OSC07 dan OSC08 berada antara kedalaman 150 - $200 \mathrm{~m}$, sedangkan di stasiun lainnya seperti OSC04 - OSC06 berada pada kedalaman $100-200 \mathrm{~m}$. Kondisi yang berbeda juga teramati pada profil salinitas di OSC10 yang memiliki pusat salinitas maksimum hanya pada kedalaman $100-150 \mathrm{~m}$. Puncak nilai salinitas maksimum ini merupakan penanda massa air South Pacific Subtropical Water (SPSW) yang dominan di Perairan Utara Papua. Di bawah lapisan ini, salinitas berkurang mencapai $\sim 34,5$ PSU pada kedalaman $750 \mathrm{~m}$. Selanjutnya, salinitas kembali bertambah terhadap kedalaman dan mencapai 34,7 PSU pada kedalaman $3000 \mathrm{~m}$.
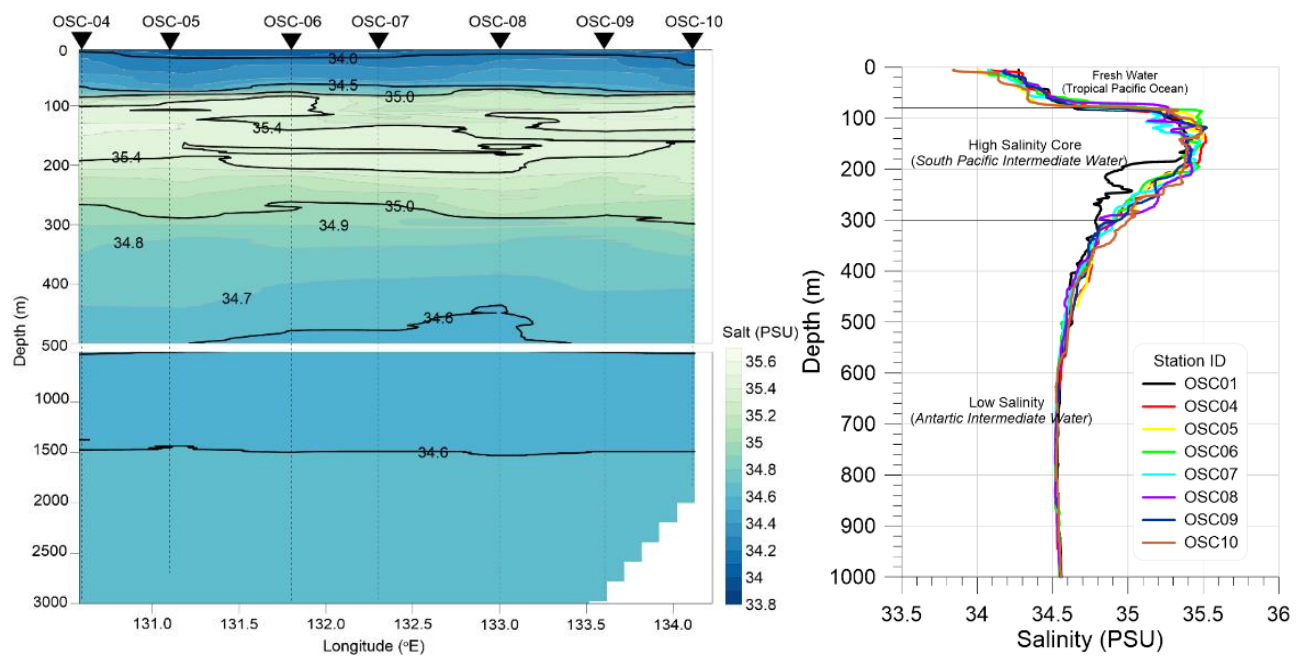

Gambar 8. a) Penampang vertikal salinitas air laut dari permukaan hingga kedalaman $3000 \mathrm{~m}$ pada transek OSC04 - OSC10 dan b) profil vertikal salinitas air laut di OSC01 dan OSC04 - OSC10 dari permukaan hingga kedalaman $1000 \mathrm{~m}$.

Figure 8. a) Vertical section of salinity from surface to 3000m depth at OSC04-OSC10 transect and b) vertical profile of salinity at OSC01 and OSC04 - OSC10 from the surface layer to $1000 \mathrm{~m}$ depth.

Adanya percampuran massa air yang sangat kuat di permukaan tercermin pula pada profil DO. Nilai DO di permukaan bervariasi antar 4,2 - 4,3 ml/L (Gambar 9), sesuai dengan hasil pengukuran massa air di perairan Utara Papua yang memiliki rentang DO sebesar $4.0-4.5 \mathrm{ml} / \mathrm{L}$ (Wyrtki, 1961). Rentang DO di permukaan laut ini secara umum lebih rendah jika dibandingkan dengan hasil penelitian di Pulau Biak oleh Tussadiah et. al. (2017) yang memiliki rentang 6.5 - $8.0 \mathrm{mg} / \mathrm{L}$ (atau $4.5-5.9 \mathrm{ml} / \mathrm{L}$ berdasarkan konversi $1 \mathrm{ml} / \mathrm{L}=1.42905 \mathrm{mg} / \mathrm{L}$ ) (USGS, 2011). Perbedaan konsentrasi oksigen di permukaan pada kedua penelitian ini dapat terjadi karena perbedaan kondisi suhu, salinitas, maupun cuaca pada saat pengukuran. Angin permukaan laut yang cenderung berhembus lebih kuat pada bulan
Agustus yang merupakan puncak monsun tenggara diduga menjadi salah satu faktor yang menyebabkan lebih tingginya konsentrasi DO di pesisir Pulau Biak. Sebaliknya, pada penelitian ini pengukuran dilaksanakan pada bulan Oktober November yang memiliki kecepatan angin relatif lebih lemah, sehingga pengadukan massa air tidak cukup kuat untuk meningkatkan konsentrasi oksigen di lapisan permukaan.

DO berkurang secara perlahan hingga mencapai nilai 4,0 di kedalaman $80 \mathrm{~m}$ yang menandai batas mixed layer. Di bawah lapisan ini terlihat adanya pengurangan nilai DO secara drastis hingga mencapai $3,0 \mathrm{ml} / \mathrm{L}$ pada kedalaman $\sim 100 \mathrm{~m}$. Hal ini berasosiasi dengan adanya lapisan termoklin dan haloklin di kedalaman tersebut. Selanjutnya di bawah lapisan ini DO kembali 
berkurang secara perlahan terhadap kedalaman dan mencapai nilai minimum $2,1 \mathrm{ml} / \mathrm{L}$ pada kedalaman 1300 m. Di bawah lapisan ini, DO kembali bertambah terhadap kedalaman hingga mencapai nilai 3,0 m/L pada kedalaman $3000 \mathrm{~m}$. Namun, di stasiun OSC06 - OSC10 terlihat adanya intrusi massa air dengan DO rendah yaitu $2,7-3,0 \mathrm{ml} / \mathrm{L}$ pada kedalaman 400 - $480 \mathrm{~m}$. Massa air dengan DO rendah ini diduga berasal dari Samudera Pasifik.
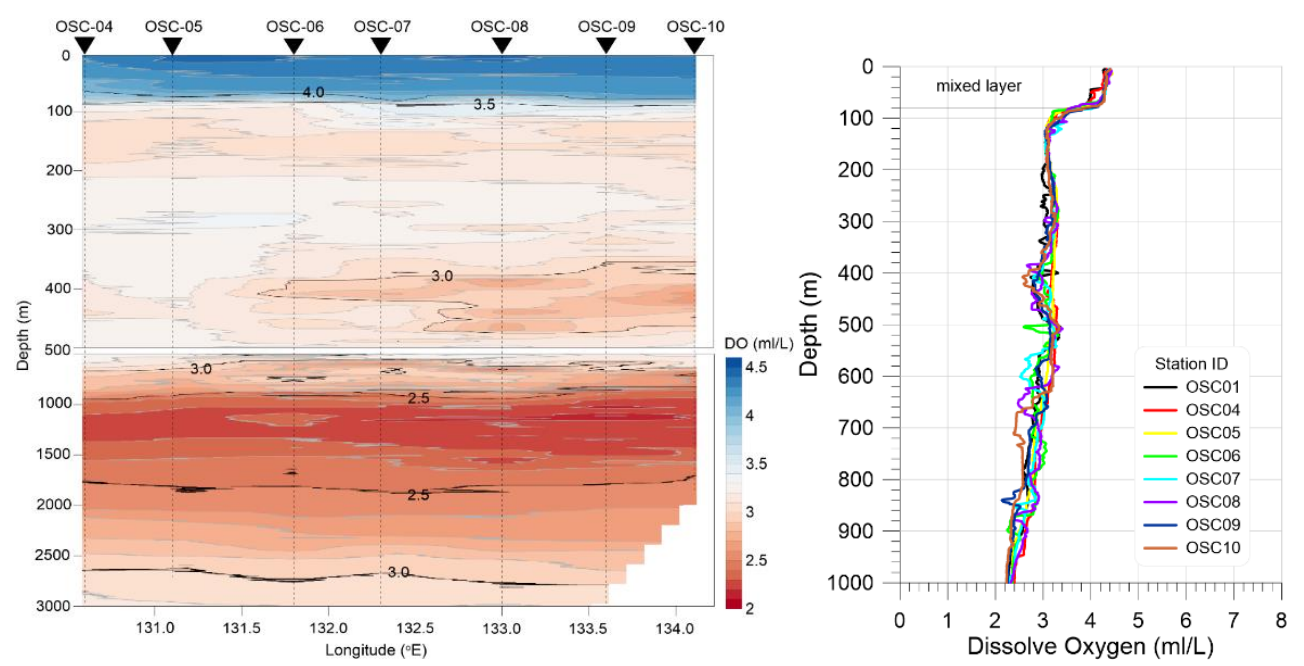

Gambar 9. a) Penampang vertikal oksigen terlarut (DO) dari permukaan hingga kedalaman $3000 \mathrm{~m}$ pada transek OSC04 - OSC10 dan b) profil vertikal DO di OSC01 dan OSC04 - OSC10 dari permukaan hingga kedalaman $1000 \mathrm{~m}$.

Figure 9. a) Vertical section of dissolved oxygen (DO) from surface to $3000 \mathrm{~m}$ depth at OSC04 - OSC10 transect and b) vertical profile of DO at OSC01 and OSC04 - OSC10 from the surface layer to 1000 $\mathrm{m}$ depth.
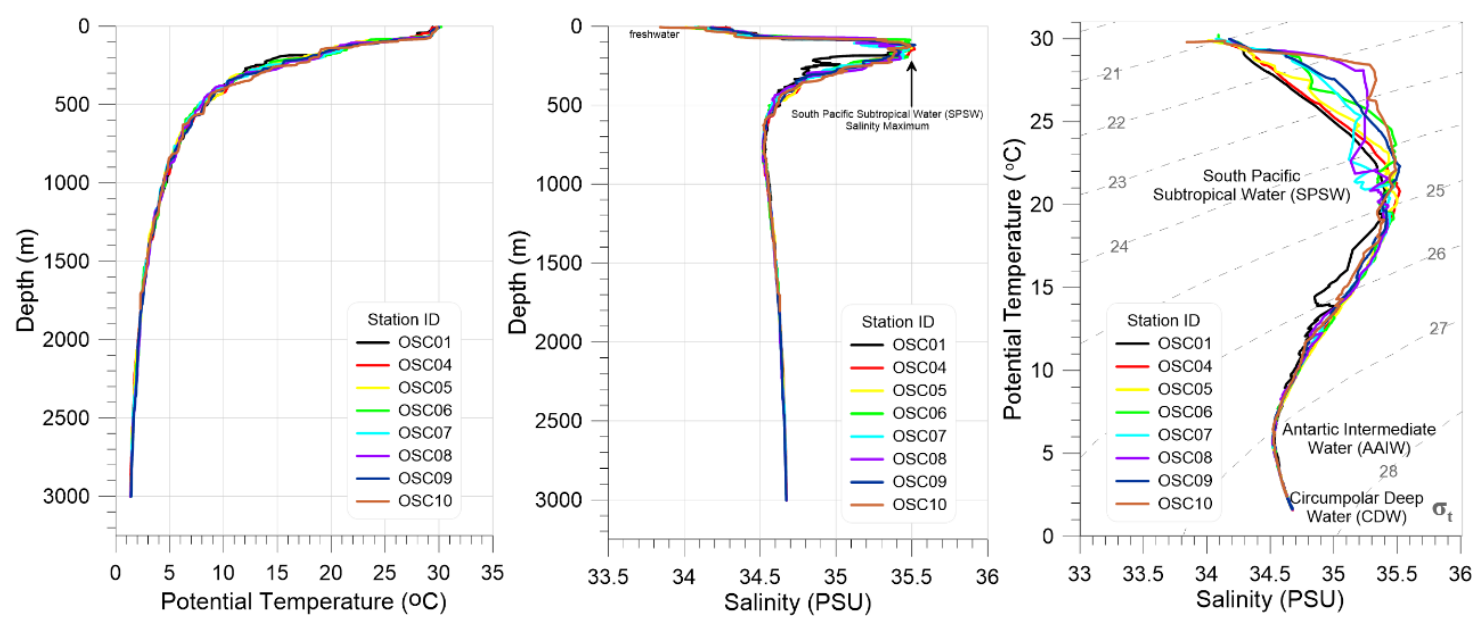

Gambar 10. a) Profil vertikal suhu air laut potensial, b) salinitas air laut dari permukaan hingga mendekati dasar perairan di setiap stasiun pengamatan, dan c) diagram T-S yang menggambarkan karakteristik massa air di Perairan Utara Papua.

Figure 10. a) Vertical profile of potential temperature, b) salinity from the surface to near-bottom of each research stations, and c) T-S diagram which explains the water mass characteristics of North Papua Waters.

Berdasarkan profil vertikal suhu dan salinitas yang direpresentasikan dalam diagram TS (Gambar 10) dapat disimpukan bahwa massa air di Perairan Utara Papua terbagi menjadi tiga jenis yaitu 1) massa air South Pacific Subtropical Water (SPSW) di bawah lapisan permukaan (kedalaman $0-500 \mathrm{~m}$ ) (Gordon, 2005; Sprintall et al., 2014); 2) massa air Antartic Intermediate Water (AAIW) 
(Emery, 2008) dan 3) massa air Circumpolar Deep Water $(C D W)$ di lapisan dalam (kedalaman $1500 \mathrm{~m}$ - dasar perairan) (Emery, 2008). Namun begitu terdapat beberapa perbedaan antara massa air di sebelah utara Laut Halmahaera (OSC01, OSC04, OSC05) dengan massa air di Perairan Utara Papua (OSC06 - OSC10). Massa air di Perairan Utara Papua cenderung memiliki gradien salinitas yang lebih tinggi dan gradien suhu yang lebih rendah di lapisan permukaan (kedalaman $0-100 \mathrm{~m}$ ). Selain itu adanya variasi kurva T-S pada garis isopiknal yang sama diduga merupakan indikasi terjadinya isopicnal ataupun diapycnal mixing ( $\mathrm{Li}$ et al., 2018).

\section{Profil massa air di sekitar PPKT}

Setelah melakukan analisis pada data profil massa air di Perairan Utara Papua, selanjutnya akan dianalisis data profil massa air di pesisir PPKT meliputi Pulau Jiew, Fani, Brass, dan Fanildo. Hasil pengukuran profil suhu air laut menunjukkan bahwa ketebalan lapisan mixed layer hampir sama dengan hasil pengukuran di laut lepas yaitu sekitar $80 \mathrm{~m}$ (Gambar 11). Akan tetapi terlihat adanya sedikit perbedaan khususnya di Stasiun OSC-FANI02 yang menunjukkan bahwa area ini memiliki lapisan mixed layer yang lebih tipis dibandingkan area lainnya. Pada kedalaman $\sim 60 \mathrm{~m}$, suhu air laut sudah berkurang secara drastis mencapai nilai $\sim 23^{\circ} \mathrm{C}$. Berkurangnya suhu secara drastis pada kedalaman ini diikuti dengan adanya peningkatan salinitas secara drastis di kedalaman tersebut. Pada kedalaman $\sim 60 \mathrm{~m}$, salinitas bertambah dan mencapai nilai 35.4 PSU. Kondisi ini berbeda dengan hasil pengukuran di OSCFANI01 yang menunjukkan adanya lapisan mixed layer yang lebih tebal hingga kedalaman $80 \mathrm{~m}$. OSC-FANI01 berada di sebelah selatan OSCFANI02, sehingga diduga massa air di OSCFANI01 lebih banyak mendapatkan pengaruh dari NGCC yang membawa massa air SPSW.

Profil yang berbeda juga terlihat pada hasil pengukuran di Pulau Brass dan Fanildo (Gambar 11). Secara umum ketiga stasiun yaitu OSCBRF01, OSC-BRF02, dan OSC-BRF03 memiliki lapisan mixed layer dengan ketebalan yang hampir sama yaitu $\sim 80 \mathrm{~m}$. Namun, ketiga area ini memiliki profil salinitas yang berbeda di lapisan mixed layer tersebut. OSC-BRF02 memiliki lapisan mixed layer dengan salinitas yang paling rendah dibandingkan kedua stasiun lainnya, yaitu berada pada rentang 34,2 - 34,3 PSU. OSC-BRF03 memiliki salinitas yang lebih tinggi di lapisan mixed layer yaitu 34,3-34,4 PSU. Berbeda halnya dengan OSC-BRF01 yang memiliki rentang salinitas lebih besar di lapisan mixed layer yaitu 34,4 - 35,4 PSU. Tingginya gradien salinitas di lapisan ini tentunya membuat massa air di OSCBRF01 memiliki stratifikasi yang lebih kuat dibandingkan kedua stasiun lainnya. Jika dilihat dari posisinya, stasiun OSC-BRF01 terletak lebih ke utara dan timur dibandingkan kedua stasiun lainnya. Hal ini diduga merupakan salah satu faktor yang menyebabkan adanya perbedaan profil salinitas secara signifikan di area ini.

Selanjutnya profil massa air yang cukup menarik juga terlihat di Pulau Budd. Berdasarkan hasil pengukuran di empat stasiun pengamatan (OSC-BUDD01 s.d. OSC-BUDD04) yang masingmasing berada di sebelah barat, selatan, timur, dan utara Pulau Budd, menunjukkan adanya percampuran yang lemah di mixed layer. Di permukaan hingga kedalaman $80 \mathrm{~m}$ baik suhu maupun salinitas tidak menunjukkan adanya percampuran yang kuat, melainkan menunjukkan adanya stratifikasi. Kondisi ini konsisten terlihat di empat stasiun pengamatan. Selanjutnya, di lapisan termoklin stratifikasi semakin menguat karena adanya gradien peningkatan salinitas yang cukup tinggi karena masuknya massa air SPSW di area ini.

\section{Pembahasan}

Perairan Utara Papua merupakan salah satu area yang menjadi perhatian karena dinamika oseanografi di area ini diduga dipengaruhi oleh kondisi laut dan atmosfer dalam skala regional (Fine et al., 1994). Hal ini terbukti dari variasi tahunan SPL yang lebih rendah dibandingkan beberapa laut di sekitarnya. SPL di Perairan Utara Papua secara dominan dipengaruhi oleh dinamika oseanografi di Samudera Pasifik bagian barat. Area ini memiliki suhu yang hangat dan variabilitas yang rendah sepanjang tahun (Wyrtki, 1961; Qu et al., 2005; Potemra \& Qu, 2010). Tingginya suhu permukaan laut di area ini disebabkan oleh lokasinya yang berada di wilayah ekuator sehingga mendapatkan pemanasan yang intensif sepanjang tahun. Selain itu berhembusnya angin pasat ke arah barat membuat massa air hangat terkonsentrasi di bagian barat Samudera Pasifik atau dikenal sebagai Western Pacific Warm Water Pool (WPWWP) (Fine et al., 1994). Berbeda halnya dengan massa air di Laut Halmahera, dan Laut Maluku yang mendapatkan pengaruh sistem angin monsun cukup kuat (Fine et al., 1994; Qu et al., 2005). Pada musim timur (Juni - September), Laut Halmahera dan Maluku cenderung memiliki suhu permukaan laut yang lebih rendah. Rendahnya SPL diduga 
merupakan akibat dari adanya upwelling di Laut Banda (Wyrtki, 1961; Qu et al., 2005; Kida \& Richards, 2009; Potemra \& Qu, 2010) yang membawa massa air dingin ke permukaan laut.
SPL yang relatif rendah di Laut Banda diduga menyebar ke area Laut Seram, Laut Maluku, dan Laut Halmahera karena adanya dorongan dari angin monsun tenggara.
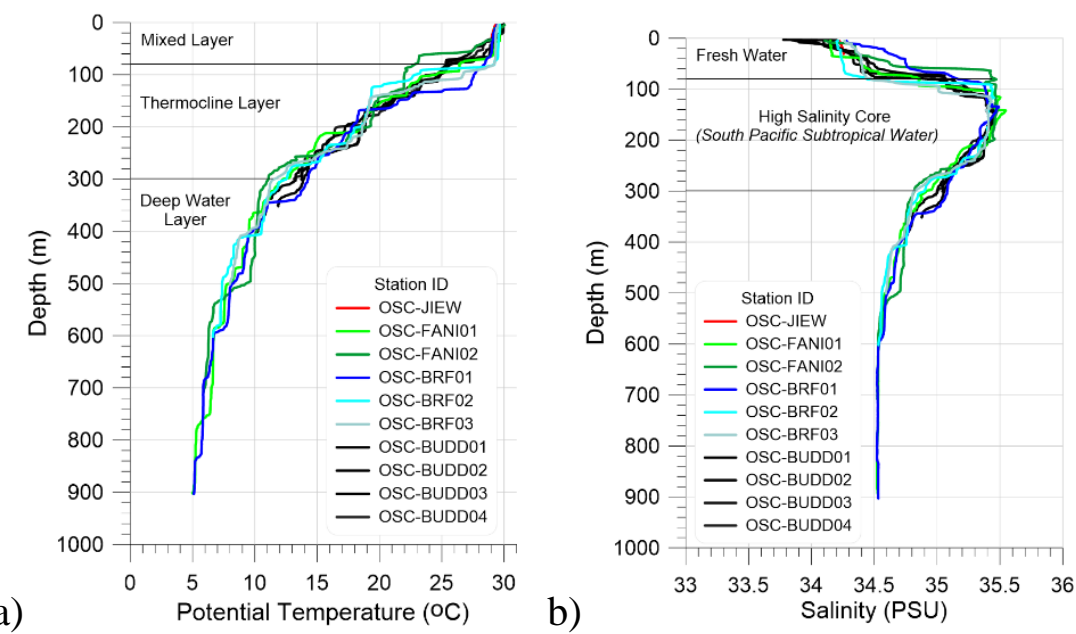

a)

b)
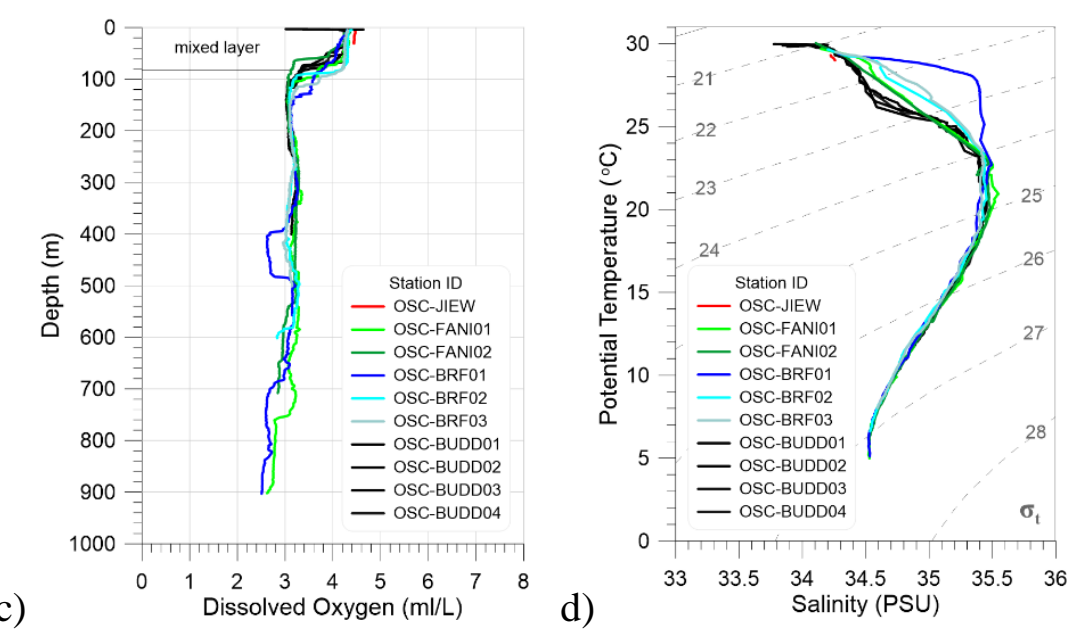

Gambar 11. a) Profil vertikal suhu air laut potensial, b) salinitas air laut, c) oksigen terlarut, dan d) diagram T$\mathrm{S}$ di setiap stasiun pengamatan di sekitar PPKT Perairan Utara Papua.

Figure 11. a) Vertical profile of potential temperature, b) salinity, c) dissolved oxygen, and d) T-S diagram around the Indonesia's outer islands at North Papua Waters.

Berdasarkan hasil pengukuran, diketahui Perairan Utara Papua memiliki mixed layer yang relatif tebal pada monsun peralihan II. Adapun ketebalan mixed layer di area ini bervariasi dari 60 hingga 100 meter yang ditandai dengan relatif homogennya suhu air laut di lapisan tersebut. Namun begitu, profil salinitas di mixed layer menunjukkan adanya stratifikasi yang kuat. Salinitas air laut terus bertambah seiring dengan bertambahnya kedalaman dan gradien peningkatan salinitas tertinggi teridentifikasi di lapisan termoklin. Di bawah lapisan permukaan, yaitu dari mixed layer hingga lapisan termoklin, Perairan
Utara Papua didominasi oleh massa air Samudera Pasifik Subtropis Selatan (South Pacific Subtropical Water - SPSW) (Fine et al., 1994). SPSW dicirikan dengan massa air yang memiliki nilai maksimum salinitas di lapisan termoklin sebesar $~ 35,2-35,5$ PSU. Namun, salinitas air laut mengalami penurunan pada kedalaman $>150 \mathrm{~m}$ yang merupakan lokasi rata-rata puncak salinitas maksimum di Perairan Utara Papua. Untuk menjaga kestabilan kolom air, gradien pengurangan suhu air laut yang tinggi masih terlihat di lapisan ini. Gradien pengurangan suhu 


\section{Surinati \& Corvianawatie}

air laut yang tinggi membentuk lapisan termoklin yang stabil hingga kedalaman $300 \mathrm{~m}$.

Secara umum tidak terdapat perbedan yang signifikan antara hasil pengukuran massa air di lepas pantai dan pesisir PPKT Perairan Utara Papua. Keduanya menunjukkan adanya dominasi pengaruh massa air SPSW di lapisan termoklin. Perbedaan justru terlihat di mixed layer antara kedua lokasi tersebut. Beberapa area memiliki mixed layer yang lebih tebal dan beberapa lainnya memiliki mixed layer yang lebih tipis. Sebagai contoh mixed layer di OSC-FANI02 teridentifikasi hingga kedalaman $60 \mathrm{~m}$, sedangkan mixed layer di OSC-BRF01 lebih tebal mencapai kedalaman 140 $\mathrm{m}$. Perbedaan ketebalan mixed layer ini bersesuaian dengan profil salinitas di lapisan tersebut. Area dengan mixed layer yang lebih tipis ditandai pula dengan lokasi puncak salinitas maksimum yang lebih dangkal. Puncak salinitas maksimum di OSC-FANIO2 dapat diidentifikasi pada kedalaman $60-200 \mathrm{~m}$. Akan tetapi puncak salinitas maksimum di OSC-BRF01 dapat diidentifkasi pada kedalaman $80-200 \mathrm{~m}$. Adanya variasi pada kedalaman mixed layer pada profil suhu secara dominan dipengaruhi oleh fluk panas di permukan dan adanya percampuran vertikal di bawah lapisan permukaan (Halkides et al., 2011).

Perbedaan profil suhu dan salinitas ini dapat terlihat lebih jelas melalui diagram T-S. Semakin ke arah timur, meliputi area OSC08 OSC10 serta Pulau Brass dan Fanildo kemiringan kurva T-S di permukaan lebih landai. Kemiringan kurva T-S yang lebih landai di lapisan permukaan menandakan adanya gradien peningkatan salinitas yang lebih tinggi dibandingkan dengan gradien penurunan suhu air laut. Sebaliknya, semakin ke arah barat meliputi area OSC01 - OSC07 serta Pulau Jiew dan Fani, kemiringan kurva T-S di lapisan permukaan jauh lebih curam. Hal ini mengindikasikan bahwa gradien peningkatan salinitas sebanding dengan gradien penurunan suhu air laut. Kondisi ini mengindikasikan bahwa massa air SPSW memasuki perairan Indonesia dari sisi timur melewati perairan pesisir Pulau Brass dan Fanildo. Menuju ke arah barat, diduga massa air ini mengalami percampuran isopiknal yang menyebabkan kurva T-S di area ini lebih curam. Dampak yang jelas terlihat yaitu perbedaan posisi kedalaman salinitas maksimum antara perairan PPKT di sisi barat dan sisi timur.

Kondisi yang unik terlihat pada kurva T-S perairan pesisir Pulau Budd. Kurva T-S menunjukkan adanya pola seperti patahan yang mengindikasikan adanya perbedaan gradien suhu dan salinitas antara mixed layer dan lapisan termoklin. Kurva T-S tersebut mengindikasikan gradien pengurangan suhu lebih kuat dibandingkan dengan gradien peningkatan salinitas di lapisan permukaan. Sebaliknya di lapisan termoklin, gradien peningkatan salinitas lebih tinggi dibandingkan dengan gradien pengurangan suhu air laut.
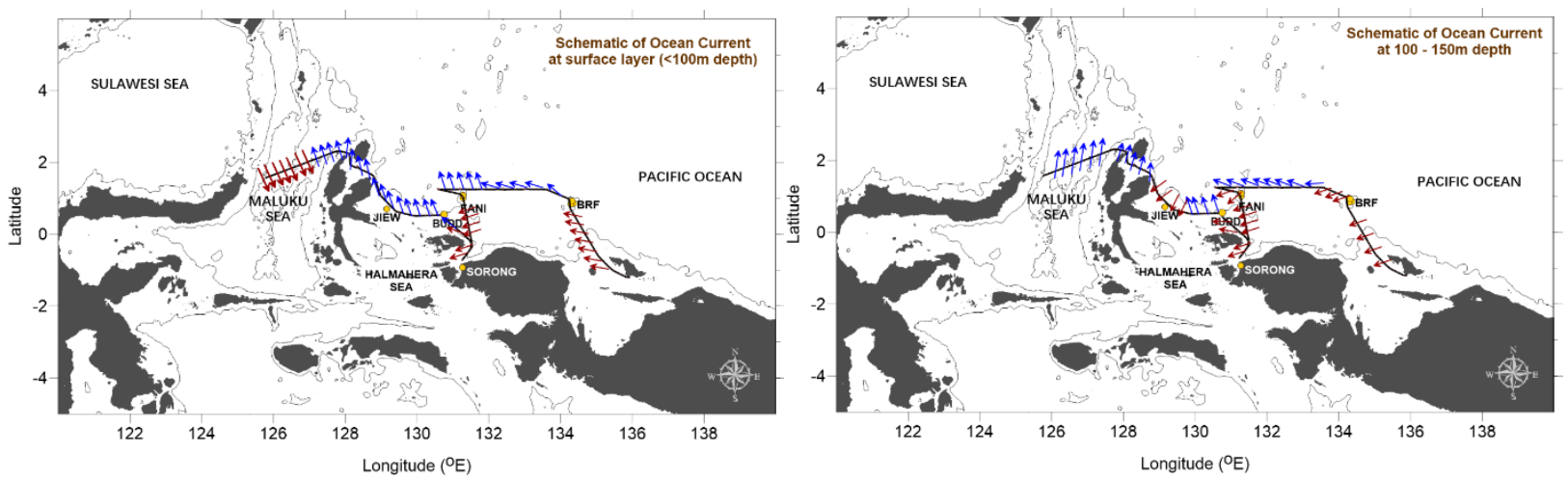

Gambar 12. Diagram skema pola arus di sekitar PPKT pada lapisan permukaan dengan kedalaman 100-150m. Keterangan: panjang tanda panah tidak mencerminkan kekuatan arus.

Figure 12. Schematic diagram of the flow pattern around PPKT at a) surface layer $(<100 \mathrm{~m} \mathrm{depth})$ and $b)$ thermocline layer $(100-150 \mathrm{~m}$ depth). Note: the length of the arrow does not reflect the strength of the ocean current.

Jika ditinjau dari pola arus yang melintas di area ini, perairan di sisi timur didominasi oleh NGCC/SEC yang bergerak ke arah barat. Menuju ke arah barat atau menuju ke Kepulauan
Halmahera, arus ini mengalami pembelokan ke arah utara dan terdorong oleh NECC sehingga membentuk pusaran arus yang disebut sebagai Halmahera Eddy. Hasil analisis menggunakan 
model numerik INDESO dan HYCOM menunjukkan adanya anticyclonic Eddy di Laut Halmahera pada kedalaman 0, 75, 150, dan 200m (Simanungkalit et al., 2018). Hal ini sesuai dengan hasil pengukuran yang menunjukkan indikasi terbentuknya anticyclonic Eddy (eddy yang berotasi searah putaran jarum jam) pada kedalaman $0-100 \mathrm{~m}$.

Arus yang bergerak ke arah barat hingga barat laut ini secara dominan terlihat di sisi timur dan barat Pulau Brass dan Fanildo dari permukaan hingga kedalaman $150 \mathrm{~m}$. Arus ini diduga merupakan salah satu sumber dalam jalur sekunder sistem ITF yang membawa massa air SPSW menuju perairan Indonesia. Kondisi yang hampir sama yaitu adanya dominasi arus laut ke arah barat hingga barat daya memasuki perairan Indonesia terlihat pula di selatan Pulau Budd dan Pulau Fani. Akan tetapi terlihat adanya beberapa perbedaan pola arus di utara Laut Halmahera, khususnya di penampang melintang antara Pulau Jiew dan Pulau Budd. Di lapisan permukaan hingga kedalaman $<100 \mathrm{~m}$, arus laut di wilayah ini dominan bergerak ke arah barat laut atau keluar dari perairan Indonesia. Hal ini diduga berasosiasi dengan masih adanya pengaruh angin monsun tenggara di Laut Halmahera. Akan tetapi, pada kedalaman 100 $150 \mathrm{~m}$, terlihat adanya arus laut menuju perairan Indonesia dari sisi tengah Laut Halmahera dan berbalik arah di sisi timur dan barat. Hasil penelitian ini menunjukkan adanya beberapa kesamaan dengan penelitian sebelumnya yang menemukan bahwa terdapat arus balik ke arah utara di sisi timur dan barat Laut Halmahera (Wattimena et al., 2018). Kompleksnya pola arus di Laut Halmahera juga terlihat hingga kedalaman $200-250 \mathrm{~m}$. Pertemuan antara arus keluar dan masuk menuju Laut Halmahera diduga berperan penting dalam mempengaruhi percampuran massa air di area ini. Hal ini terbukti dari gradien penurunan suhu dan peningkatan salinitas yang lebih rendah dibandingkan dengan massa air di sisi timur Perairan Utara Papua.

Di pesisir PPKT, arus laut memiliki pola yang hampir sama dengan hasil pengukuran di lepas pantai, kecuali di pesisir Pulau Jiew. Pengukuran arus laut di Pulau Jiew mengambil lokasi yang terlalu dekat dengan wilayah pantai sehingga dominasi arus pasang surut terlihat lebih dominan di area ini. Berbeda halnya dengan hasil pengukuran di Pulau Brass dan Fanildo yang didominasi oleh arus laut yang bergerak ke arah barat laut hingga timur laut. Selanjutnya pola arus di Pulau Fani dan Budd menunjukkan adanya variabilitas yang lebih kompleks. Di lapisan permukan hinga kedalaman $<100 \mathrm{~m}$, arus laut bergerak ke arah barat laut hingga barat daya. Akan tetapi pada kedalaman $100-150 \mathrm{~m}$ arus laut mulai dominan bergerak ke arah barat daya atau masuk menuju perairan Indonesia.

\section{Kesimpulan}

Perairan Utara Papua merupakan area yang memiliki suhu permukaan laut yang relatif hangat sepanjang tahun karena area ini merupakan bagian dari Western Pacific Warm Water Pool. Kelebihan dari adanya kolam air hangat Samudera Pasifik ini adalah variasi SPL yang lebih kecil dibanding area lainnya di perairan Indonesia. Selain itu, arus laut di area ini cukup kuat dengan adanya pengaruh pasang surut dan sistem arus regional yaitu NGCC dan SEC di Samudera Pasifik bagian barat. Perairan di sekitar Pulau Fani, Budd, Brass, dan Fanildo diketahui menjadi salah satu area lintasan ITF yang membawa massa air SPSW memasuki perairan Indonesia. Massa air SPSW dibawa oleh NGCC dan SEC dari Samudera Pasifik menuju perairan Indonesia melalui Laut Halmahera. Akan tetapi pola arus dan batimetri yang lebih kompleks di pintu masuk Laut Halmahera diduga merupakan salah satu penyebab terjadinya percampuran isopiknal ataupun diapiknal massa air di area ini. Hal ini terbukti dari adanya perbedaan kemiringan (slope) kurva T-S antara sisi timur dan barat dalam area penelitian. Variasi pada kurva T-S di Perairain Utara Papua dan pesisir PPKT cukup tinggi terutama di lapisan permukaan hingga kedalaman $200 \mathrm{~m}$ yang merupakan lokasi puncak salinitas maksimum massa air SPSW. Dengan adanya variasi SPL yang minim, arus laut yang cukup kuat, dan adanya proses percampuran massa air yang cukup kuat di beberapa area, perairan sekitar PPKT memiliki beberapa potensi untuk pengembangan ekosistem kelautan. Asesmen lanjutan mengenai jenis ekosistem kelautan yang akan dikembangkan tentunya perlu dilakukan untuk memperoleh hasil yang optimal sesuai dengan kondisi lingkungan perairan yang ada.

\section{Persantunan}

Penelitian ini didanai melalui Program Ekspedisi Nusa Manggala, COREMAP-CTI Pusat Penelitian Oseanografi LIPI tahun anggaran 2018. Kami mengucapkan terima kasih kepada koordinator besar, koordinator tema dan koordinator lapangan yang telah memfasilitasi kami sebagai tim ENM serta crew ABK 
K.R.Baruna Jaya VIII atas kerjasamanya selama pengambilan data.

\section{Daftar Pustaka}

Aji, T., Pranowo, W.S., Harsono, G., \& Alam, T.M. (2017). Seasonal Variability of Thermocline, Sound Speed and Probable Shadow Zone in Sunda Strait, Indonesia. Omni-Akuatika, 13 (2), 111 - 127.

BPS. (2018). Statistik Indonesia - Statistical Yearbook of Indonesia 2018. Badan Pusat Statistik. 719pp.

De Deckker, P. (2016). The Indo-Pacific Warm Pool: critical to world oceanography and world climate. Geoscience Letter, 3(20), 1 $-12$.

Emery, W. J. (2008). Water Types and Water Masses. Encyclopedia of Ocean Sciences: Second Edition, 291-299. https://doi.org/10.1016/B978-0123744739.00108-9.

Fine, R. A., Lukas, R., Bingham, F. M., Warner, M. J., \& Gammon, R. H. (1994). The western equatorial Pacific: A water mass crossroads. Journal of Geophysical Research, $99(\mathrm{C} 12), \quad 25063$. https://doi.org/10.1029/94JC02277.

Gordon, A. L. (2005). Oceanography of the Indonesian Seas and Their Throughflow. Oceanography, 18(4), 14-27. https://doi.org/10.5670/oceanog.2005.18.

Gordon, A. L., \& Fine, R. A. (1996). Pathways of water between the Pacific and Indian oceans in the Indonesian seas. Nature. https://doi.org/10.1038/379146a0.

Gordon, A. L., Sprintall, J., Van Aken, H. M., Susanto, R. D., Wijffels, S., Molcard, R., A. Ffield, Pranowo, W., \& Wirasantosa, S. (2010). The Indonesian throughflow during 2004-2006 as observed by the INSTANT program. Dynamics of Atmospheres and Oceans, 50(2), 115-128. https://doi.org/10.1016/j.dynatmoce.2009. 12.002.

Halkides, D., Lee, T., \& Kida, S. (2011). Mechanism controlling the seasonal mixed-layer temperature and salinity of the Indonesian seas. Ocean Dynamics, 61, 481 $-495$.

Ismail, M.F.A., \& Ribbe, J. (2019). On the crossshelf exchange driven by frontal eddies along a western boundary current during austral winter 2007. Estuarine, Coastal and Shelf Science, ISSN 0272-7714, https://doi.org/10.1016/j.ecss.2019.10631 4.

Kida, S., \& Richards, K. J. (2009). Seasonal sea surface temperature variability in the Indonesian Seas, Journal of Geophysical Research, 114: C06016, 1 - 17.

Koch-Larrouy, A., Madec, G., Iudicone, D., Atmadipoera, A., \& Molcard, R. (2008). Physical processes contributing the water mass transformation of the Indonesian Throughflow, Ocean Dynamics, 58, 275 288.

Li, B., Yuan, D., \& Zhou, H. (2018). Water masses in the far western equatorial Pacific during winters of 2010 and 2012, Chinese Journal of Oceanology and Limnology, 36(5), 1459 $-1474$.

Philander, S. G. H. (1983). El Niño Southern Oscillation phenomena. Nature, 302(5906), 295-301. https://doi.org/10.1038/302295a0.

Potemra, J. T., \& Qu, T. (2010). Seas of Southeast Asia. Encyclopedia of Ocean Sciences, 305-316. https://doi.org/10.1016/B978012374473-9.00598-1.

Qu, T., Du, Y., Strachan, J., Meyers, G., \& Slingo, J. (2005). Temperature and its variability in the Indonesia Region. Oceanography, 18(4), 50-61. https://doi.org/10.5670/oceanog.2005.05

Simanungkalit, Y.A., Pranowo, W.S., Purba, N.P., Riyantini, I., \& Nurrahman. Y. (2018). Influence of El Niño Southern Oscillation (ENSO) phenomena on Eddies Variability in the Western Pacific Ocean. IOP Conf. Series: Earth and Environmental Science, $176 \quad 012002$ doi:10.1088/17551315/176/1/012002.

Sprintall, J., Gordon, A. L., Koch-Larrouy, A., Lee, T., Potemra, J. T., Pujiana, K., \& Wijffels, S. E. (2014). The Indonesian seas and their role in the coupled ocean-climate system. Nature Geoscience, 7(7), 487-492. https://doi.org/10.1038/ngeo2188.

Supangat, A., Adi, T.R., Pranowo, W.S., \& Ningsih, N.S. (2015). Predicting Movement of the Warm Pool, the Salinity Front, and the Convergence Zone in the Western and Central Part of Equatorial Pacific Using a Coupled HydrodynamicalEcological Model. The Twelfth OMISAR Workshop on Ocean Models. 11pp.

Tussadiah, A., Subandriyo, J., Novita, S., \& Pranowo, W.S. (2017). Verification of Pisces Dissolved Oxygen Model Using in 
situ Measurement in Biak, Rote and Tanimbar Seas, Indonesia. International Journal of Remote Sensing and Earth Sciences (IJReSES), 14(1), 37-46.

Wattimena, M. C., Atmadipoera, A. S., Purba, M., Nurjaya, I. W., \& Syamsudin, F. (2018). Indonesian Throughflow (ITF) variability in Halmahera Sea and its coherency with New Guinea Coastal Current. IOP Conference Series: Earth and Environmental Science, 176(1). https://doi.org/10.1088/17551315/176/1/012011.

Wyrtki, K. (1961). Physical oceanography of the Southeast Asian waters. NAGA report, volume 2, Scientific Results of Marine Investigations of the South China Sea and the Gulf of Thailand 1959-1961. La Jolla, California: The University of California, Scripps Institution of Oceanography. $195 \mathrm{pp}$.

Yuan, D., Li, X., Wang, Z., Li, Y., Wang, J., Yang, Y., \& Storch, J.-S. von. (2018). Observed Transport Variations in the Maluku Channel of the Indonesian Seas Associated with Western Boundary Current Changes. Journal of Physical Oceanography, 48(8), 1803-1813. https://doi.org/10.1175/JPOD-17-0120.1. 